\title{
PENGARUH PENERAPAN PENDEKATAN KONTEKSTUAL DAN KREATIVITAS SISWA TERHADAP KEMAMPUAN MENULIS PUISI DI SMP NEGERI 1 ATINGGOLA
}

\author{
Sardianah*, Muslimin**, Salam** \\ *SMP Negeri 1 Atinggola: sardianahdian1985@gmail.com \\ **Universitas Negeri Gorontalo: musiyan82@gmail.com \\ ***Universitas Negeri Gorontalo: salamtolaki@ung.ac.id
}

\begin{abstract}
Abstrak
Penelitian ini bertujuan untuk memperoleh gambaran yang jelas tentang pengaruh penerapan teknik menulis dan kreativitas terhadap hasil belajar menulis puisi pada siswa SMP Negeri 1 Atinggola. Penelitian ini menggunakan metode eksperimen, dengan melibatkan dua variabel bebas, yaitu teknik konstruktivisme dan pemodelan; dan satu variabel yang dikendali (atribut) yaitu kreativitas siswa, yang dibagi atas kreativitas tinggi dan kreativitas rendah; serta satu variabel terikat yaitu hasil belajar menulis puisi. Desain penelitian yang digunakan adalah desain faktorial $2 \times 2$. Sementara, data penelitian diperoleh melalui tes unjuk kerja menulis puisi pada siswa yang menjadi sampel penelitian. Hasil penelitian ini menemukan: (1) secara keseluruhan hasil belajar menulis puisi bagi siswa yang belajar dengan teknik konstruktivisme maupun yang belajar dengan metode pemodelan memberikan perbedaan yang signifikan. Ini berati bahwa teknik konstruktivisme memberikan pengaruh yang lebih besar terhadap hasil belajar menulis puisi jika dibandingkan dengan metode pemodelan; (2) bagi siswa yang mempunyai kreativitas tinggi, teknik konstruktivisme memberikan hasil belajar menulis puisi yang lebih besar jika dibandingkan dengan hasil belajar menulis puisi melalui metode pemodelan; (3) bagi siswa yang mempunyai kreativitas rendah, teknik konstruktivisme memberikan hasil belajar menulis puisi yang lebih kecil jika dibandingkan dengan hasil belajar menulis puisi melalui metode pemodelan; dan (4) terdapat interaksi antara teknik menulis dan kreativitas terhadap hasil belajar menulis puisi. Ini berarti bahwa teknik konstruktivisme lebih unggul daripada metode pemodelan bagi siswa yang mempunyai kreativitas tinggi, sedangkan bagi siswa yang mempunyai kreativitas rendah lebih cocok dengan metode pemodelan.
\end{abstract}

Kata Kunci: Teknik Konstruktivisme, Kreativitas, Hasil Belajar, Menulis Puisi

\section{PENDAHULUAN}

Sastra sebagai karya kreatif sejak dini didekatkan dan dikomunikasikan dengan siswa melalui kegiatan pembelajaran. Pembelajaran menjadi wahana penting untuk menumbuhkan kecintaan siswa terhadap sastra. Dengan sasar kecintaan, maka siswa mempunyai wawasan dan mampu mengapresiasikan karya sastra dengan baik sesuai dengan kemampuan bakat dan kreativitas yang dimiliki. Karena itu, pembelajaran tidak hanya difokuskan pada teori, tetapi dituntut kegiatan aplikatif siswa yang dapat meningkatkan daya apresiasi mereka terhadap karya-karya sastra yang ada.

Objek pembelajaran sastra salah satunya adalah puisi. Melalui materi puisi, siswa dibelajarkan untuk dapat mengungkapkan emosi dan ekspresi mereka secara tertulis. Melalui pembelajaran menulis puisi siswa diberi latihan-latihan untuk mengekspresikan ide, pendapat, dan perasaannya mulai dari bentuk puisi sederhana sampai pada puisi yang bernilai estetika. Puisi sederhana adalah puisi yang ditulis untuk tujuan mengekspresikan isi hati dan pikiran penulisnya, sedangkan puisi yang bernilai estetika adalah puisi yang ditulis dengan memenuhi standar keindahan dengan menampilkan diksi, rima, majas, citraan, tipografi, dan aturan menulis puisi lainnya secara menarik.

Menghasilkan karya puisi tentu harus dibekali dengan pengetahuan bahasa serta pemanfaatannya untuk menghasilkan karya puisi yang sarat makna. Pengetahuan kebahasaan dalam sastra tidak harus sama persis dengan pengetahuan kebahasaan secara umum di dalam implementasinya. Sebab, dalam dunia sastra dikenal yang namanya kebebasan penggunaan bahasa tanpa harus mengikuti kaidah berbahasa yang baku. Itu dikenal dengan istilah licentia poetica. Melalui kebebasan penggunaan bahasa, maka 
pengarang dapat memanipulasi bahasa yang digunakan agar menimbulkan nilai estetika dalam karyanya. Atmzaki (1993:70) berpandangan bahwa konsep licentia poetica bertujuan agar penulis puisi tidak terbebani dengan aturan-aturan berbahasa sehingga puisi yang dihasilkan benar-benar alami, fleksibel, dan wajar.

Perwujudan lain dari kebebasan penggunaan bahasa dalam karya sastra adalah penggunaan citraan oleh penyair dalam mengungkapkan emosi, daya citra, atau daya gambar dalam puisinya agar dapat diserap secara inderawi oleh pembaca atau pendengar. Penyair memanfaatkan citraan untuk menimbulkan suasana yang khusus, yang membuat gambaran-gambaran dalam pikiran dan penginderaan dan juga untuk menarik perhatian. Akibat pemanfaatan citraan, kepuitisan dapat pula diciptakan (Hasanuddin, 2001:110).

Menghasilkan karya puisi bagi siswa harus dilatihkan dan dibiasakan sejak dini agar mereka memiliki kemampuan dan kecintaan terhadap sastra, khususnya puisi. Pembiasaan dan pelatihan sangat tepat dilakukan melalui proses pembelajaran di sekolah. Karena itu, pembelajaran kontekstual menjadi salah satu pilihan yang dapat mengembangkan kreativitas siswa dalam berpuisi. Hal ini seperti yang telah dipaparkan melalui Depdiknas (2005:46) bahwa Pengajaran kontekstual memungkinkan siswa menguatkan, memperluas, dan menerapkan pengetahuan dan kemampuan akademik mereka dalam berbagai macam tatanan dalam sekolah dan di luar sekolah agar siswa dapat memecahkan masalah-masalah dunia nyata atau masalah-masalah yang distimulasikan.

Pendekatan pembelajaran kontekstual sangat baik digunakan untuk mengasah kreativitas siswa, misalnya kemampuan untuk membuat kombinasi-kombinasi baru, menghubungkan hal-hal yang sudah ada sebelumnya. Jahja (2011:68) kreativitas dapat diartikan sebagai suatu kemampuan untuk menciptakan suatu produk baru. Kreativitas juga berhubungan dengan kemampuan untuk membuat kombinasi-kombinasi baru atau melihat hubungan-hubungan baru antar unsur, data atau hal-hal yang sudah ada sebelumnya.

Muara pembelajaran yang baik akan menghasilkan siswa yang memiliki kemampuan menulis puisi secara baik. Istilah kemampuan oleh Semiawan (1984:1) bermakna sesuatu daya yang dimiliki oleh seseorang sebagai hasil dari adanya latihanlatihan. Kemudian, Gagne (1977:4) menekankan bahwa kemampuan itu hasil yang diperoleh pembelajar setelah mengikuti pembelajaran. Dengan demikian, kemampuan adalah sebuah hasil dari proses pembelajaran yang dilakukan, hasil dari belajar.

Menulis puisi merupakan aktivitas kreatif yang berlangsung selama proses pembelajaran dengan materi atau tujuan pembelajaran siswa mampu menulis puisi kreatif dan puisi bebas. Pranoto (2004:9) mendefinisikan menulis sebagai ungkapan atau ekspresi perasaan yang dituangkan dalam bentuk tulisan. Ekspresi perasaan dalam bentuk puisi merupakan hasil kreativitas siswa. Menulis kreatif artinya hasil tulisan berupa hasil ciptaan seseorang yang tentu saja sifatnya baru. Oleh karena itu, puisi tidak sebagai literatur tetapi sebagai perwujudan manusia, yang menjadi sumber segala kreativitas (Agni, 2009:7).

Bahasa yang digunakan dalam puisi berbeda dengan yang digunakan sehari-hari. Puisi menggunakan bahasa yang ringkas namun maknanya sangat kaya. Kata-kata yang digunakannya adalah kata-kata konotatif yang mengandung banyak penafsiran atau pengertian (Kosasih, 2012:97). Oleh karena itu, puisi terdiri dari unsur-unsur pembentuknya. Unsur fisik terdiri atas. Pertama, diksi (pemilihan kata) kata-kata yang digunakan dalam puisi merupakan hasil pemilihan yang sangat cermat. Kata-katanya merupakan hasil pertimbangan baik itu makna, susunan bunyinya, maaupun hubungan kata itu dengan kata-kata lain dalam baris dan baitnya.

Pembelajaran puisi melalui pendekatan kontekstual menjadi salah satu metode pembelajaran yang memusatkan aktivitasnya 
pada siswa. Hal ini seperti yang dikemukakan oleh Sanjaya (2008:225) bahwa pembelajaran kontekstual suatu strategi pembelajaran yang menekankan kepada proses keterlibatan siswa secara penuh untuk dapat menemukan materi yang dipelajari dan menghubungkannya dengan situasi kehidupan nyata sehingga mendorong sswa untuk menerapkannya dalam kehidupan mereka. Sa'ud (2009:168) mendata tujuh asa komponen pembelajaran kontekstual yang melandasi pelaksanaannya, yaitu: (1) Konstruktivisme, (2) Inkuiri, (3) Bertanya, (4) Masyarakat belajar, (5) Permodelan, (6) Refleksi, dan (7) Penilaian nyata.

Kelancaran proses pembelajaran ditunjang oleh kreativitas yang harus dimiliki setiap siswa. Kreativitas merupakan aktivitas mental karena berkaitan dengan pemahaman manusia terhadap lingkungannya secara terusmenerus dengan penuh ketekunan dan kesabaran yang mengahasilkan berbagai ide, temua, cara-cara baru, dan berbagai tindakan yang merupakan terobosan bagi suatu perubahan yang sangat bernilai dan bermakna bagi manusia dalam mengembangkan, mengatur, dan mengendalikan lingkungannya sehingga memberikan manfaat bagi kehidupan manusia dan lingkungannya (Jamaris, 2013:74).

\section{METODE PENELITIAN}

Penelitian ini dilakukan pada bulan Januari-Februari 2019 di kelas VIII SMP Negeri 1 Atinggola Kabupaten Gorontalo Utara. Metode yang digunakan dalam penelitian ini adalah penelitian eksperimental dengan menggunakan desain dua faktorial. Populasi dalam penelitian ini adalah seluruh siswa (siswa) kelas VIII di SMP Negeri 1 Atinggola yang berjumlah 108 orang. Peneraikan sampel pada penelitian ini dilakukan dengan teknik stage random sampling, yaitu dengan memilih secara acak kelas yang akan dijadikan sampel penelitian.

Penelitian ini menerapkan kontrol validitas, baik internal maupun eksternal.
Validitas internal dilakukan pada rancangan penelitian eksperimental untuk mengetahui apakah manipulasi eksperimental yang dilakukan pada saat studi ini benar-benar menimbulkan perbedaan. Validitas ekstenal dilakukan untuk melihat kerepresentatifan penemuan penelitian dan berkaitan dengan penggeneralisasian pada kondisi yang sama. Pengumpulan data melalui tes kemampan menulis puisi dengan aspek penilaian berikut. (1) kesesuaian tema dengan isi, (2) ketepatan diksi, dan (3) kedalaman gagasan. Dalam tes kreativitas menggunakan kuesioner dengan skala likert skor 1-4, yaitu pernyataan selalu (skor 4), sering (skor 3), kadang-kadang (skor 2), dan tidak pernah (skor 1).

Analisis data dilakukan dengan teknik analisis data deskriptif dan analisis data inferensial. Analisis data deskriptif disajikan melalui tabel distribusi frekuensi, histogram, dan rata-rata simpangan baku. Analisis data inferensial untuk menguji hipotesis dengan sebelumnya melakukan uji normalitas dan uji homogenitas data penelitian dengan rumus Lilliefors. Analisis inferensial yang digunakan adalah analisis varians (ANAVA) dua jalur yang didasarkan atas pengumpulan data dalam penelitian ini.

\section{HASIL PENELITIAN DAN PEMBAHASAN \\ Hasil Penelitian}

\section{A. Data hasil penelitian}

1. Data Hasil Belajar Menulis Puisi bagi Siswa dengan Metode Konstruktivisme dalam Pendekatan Kontekstual

Dalam kelompok ini skor hasil belajar menulis puisi dengan metode konstruktivisme dalam pendekatan kontekstual tertinggi adalah 29 dan terendah 10. Adapun harga rata-rata sebesar 19.32, Median 17.50 dan Modus 19.10. Distribusi frekwensi hasil belajar menulis puisi dengan metode konstruktivisme dalam pendekatan kontekstual, seperti pada Tabel 1 . 
Tabel 1. Daftar Distribusi Hasil Belajar Menulis Puisi dengan Metode Konstruktivisme dalam Pendekatan Kontekstual

\begin{tabular}{|c|c|c|c|c|c|c|c|c|}
\hline No. & \multicolumn{3}{|c|}{ Kelas Interval } & $\mathbf{X}_{\mathbf{0}}$ & Frek. Absolut & ci & cifi & Frek. Relatif (\%) \\
\hline 1 & 10 & - & 13 & 11.5 & 4 & -2 & -8 & 18.18 \\
\hline 2 & 14 & - & 17 & 15.5 & 5 & -1 & -5 & 22.73 \\
\hline 3 & 18 & - & 21 & 19.5 & 5 & 0 & 0 & 22.73 \\
\hline 4 & 22 & - & 25 & 23.5 & 4 & 1 & 4 & 18.18 \\
\hline 5 & 26 & - & 29 & 27.5 & 4 & 2 & 8 & 18.18 \\
\hline \multicolumn{3}{|c|}{ Jumlah } & $\mathbf{2 2}$ & & $-\mathbf{1}$ & $\mathbf{1 0 0 . 0 0}$ \\
\hline
\end{tabular}

2. Data Hasil Belajar Hasil Belajar Menulis Puisi dengan Metode Pemodelan dalam Pendekatan Kontekstual

Dalam kelompok ini skor hasil belajar menulis puisi dengan metode pemodelan dalam pendekatan kontekstual

tertinggi adalah 25 dan terendah 9. Adapun harga rata-rata sebesar 17.32, Median 16.50 dan Modus 21,00. Distribusi frekwensi data hasil belajar menulis puisi dengan metode pemodelan dalam pendekatan kontekstual, seperti pada Tabel 2.

Tabel 2. Daftar Distribusi Data Hasil Belajar Menulis Puisi dengan Metode Pemodelan dalam Pendekatan Kontekstual

\begin{tabular}{|c|c|c|c|c|c|c|c|c|}
\hline No. & \multicolumn{3}{|c|}{ Kelas Interval } & $\mathbf{X}_{\mathbf{0}}$ & Frek. Absolut & ci & cifi & Frek. Relatif (\%) \\
\hline 1 & 8 & - & 10 & 9 & 1 & -2 & -2 & 4.55 \\
\hline 2 & 11 & - & 13 & 12 & 4 & -1 & -4 & 18.18 \\
\hline 3 & 14 & - & 16 & 15 & 4 & 0 & 0 & 18.18 \\
\hline 4 & 17 & - & 19 & 18 & 6 & 1 & 6 & 27.27 \\
\hline 5 & 20 & - & 22 & 21 & 4 & 2 & 8 & 18.18 \\
\hline 6 & 23 & - & 25 & 24 & 3 & 3 & 9 & 13.64 \\
\hline \multicolumn{3}{|c|}{ Jumlah } & $\mathbf{2 2}$ & & $\mathbf{1 7}$ & $\mathbf{1 0 0 . 0 0}$ \\
\hline
\end{tabular}

3. Data Hasil Belajar Menulis Puisi bagi terendah 9. Adapun harga rata-rata sebesar Siswa yang Memiliki Kreativitas 19.50, Median 19.50, dan Modus 19.50. Tinggi Distribusi frekwensi hasil belajar menulis

Dalam kelompok ini skor hasil belajar menulis puisi yang memiliki puisi yang memiliki kreativitas tinggi, seperti pada Tabel 3 .

kreativitas tinggi tertinggi adalah 29 dan

Tabel 3. Daftar Distribusi Data Hasil Belajar Menulis Puisi bagi Siswa yang Memiliki

Kreativitas Tinggi

\begin{tabular}{|c|c|c|c|c|c|c|c|c|}
\hline No. & \multicolumn{3}{|c|}{ Kelas Interval } & $\mathbf{X}_{\mathbf{0}}$ & Frek. Absolut & ci & cifi & Frek. Relatif (\%) \\
\hline 1 & 8 & - & 11 & 9.5 & 2 & -2 & -4 & 9.09 \\
\hline 2 & 12 & - & 15 & 13.5 & 5 & -1 & -5 & 22.73 \\
\hline 3 & 16 & - & 19 & 17.5 & 4 & 0 & 0 & 18.18 \\
\hline 4 & 20 & - & 23 & 21.5 & 4 & 1 & 4 & 18.18 \\
\hline 5 & 24 & - & 27 & 25.5 & 5 & 2 & 10 & 22.73 \\
\hline 6 & 28 & - & 31 & 29.5 & 2 & 3 & 6 & 9.09 \\
\hline \multicolumn{5}{|c|}{ Jumlah } & 22 & & 11 & 100.00 \\
\hline
\end{tabular}

4. Data Hasil Belajar Menulis Puisi bagi Siswa yang Memiliki Kreativitas Rendah

Dalam kelompok ini skor hasil belajar menulis puisi bagi siswa yang memiliki kreativitas rendah tertinggi adalah
25 dan terendah 10. Adapun harga rata-rata sebesar 17.91, Median 17.50 dan Modus 18.10. Distribusi frekwensi hasil belajar menulis puisi bagi siswa yang memiliki kreativitas rendah, seperti pada Tabel 4. 
Tabel 4. Daftar Distribusi Data Hasil Belajar Menulis Puisi bagi Siswa yang Memiliki Kreativitas Rendah

\begin{tabular}{|c|c|c|c|c|c|c|c|c|}
\hline No. & \multicolumn{3}{|c|}{ Kelas Interval } & $\mathrm{X}_{0}$ & Frek. Absolut & ci & cifi & Frek. Relatif (\%) \\
\hline 1 & 9 & - & 11 & 10 & 2 & -2 & -4 & 9.09 \\
\hline 2 & 12 & - & 14 & 13 & 3 & -1 & -3 & 13.64 \\
\hline 3 & 15 & - & 17 & 16 & 5 & 0 & 0 & 22.73 \\
\hline 4 & 18 & - & 20 & 19 & 5 & 1 & 5 & 22.73 \\
\hline 5 & 21 & - & 23 & 22 & 5 & 2 & 10 & 22.73 \\
\hline 6 & 24 & - & 26 & 25 & 2 & 3 & 6 & 9.09 \\
\hline \multicolumn{5}{|c|}{ Jumlah } & 22 & & 14 & 100.00 \\
\hline
\end{tabular}

\section{B. Pengujian Persyaratan Analisis Data}

1. Uji Normalitas Data

Pengujian normalitas data ini dilakukan melalui Uji Liliefors dengan $\alpha=$ 0,05 . Kriteria pengujiannya adalah: tolak hipotesis nol bahwa populasi berdistribusi normal jika $\mathrm{L}_{0}$ yang diperoleh dari data pengamatan lebih besar $\mathrm{L}_{\text {tabel}}$, dalam hal lainnya hipotesis nol diterima. Pengujian normalitas pada penelitian ini dilakukan terhadap delapan kelompok data sebagai berikut.

a. Data hasil belajar menulis puisi bagi siswa yang memiliki kreativitas tinggi melalui teknik konstruktivisme;

b. Data hasil belajar menulis puisi bagi siswa yang memiliki kreativitas rendah melalui teknik konstruktivisme;

c. Data hasil belajar menulis puisi bagi siswa yang memiliki kreativitas tinggi melalui pemodelan;

d. Data hasil belajar menulis puisi bagi siswa yang memiliki kreativitas rendah melalui pemodelan;

e. Data hasil belajar menulis puisi bagi siswa melalui teknik konstruktivisme;

f. Data hasil belajar menulis puisi bagi siswa melalui pemodelan; g. Data hasil belajar menulis puisi bagi siswa melalui yang memiliki kreativitas tinggi;

h. Data hasil belajar menulis puisi bagi siswa melalui memiliki kreativitas rendah;

Berdasarkan hasil pengujian, dapat disimpulkan bahwa sampel dari kedelapan kelompok di atas adalah berasal dari populasi yang berdistribusi normal. Kesimpulan tersebut membawa akibat terhadap diperbolehkannya menggunakan statistika parametrik dalam pengujian hipotesis penelitian ini. Adapun persyaratan lain yang dilakukan adalah pengujian homogenitas variansi. Pengujian hipotesis penelitian ini dilakukan dengan teknik Analisis Varian Dua jalur (ANAVA $2 \times 2$ ), kemudian dilakukan uji lanjut dengan menggunakan uji Tukey.

Analisis Variansi dua jalur adalah suatu teknis perhitungan (statistik parametrik) yang bertujuan untuk menyelidiki dua pengaruh, yaitu pengaruh utama (main effect) dan pengaruh interaksi (interaction effect). Pengaruh utama disini adalah pengaruh perbedaan teknik menulis puisi (teknik konstruktivisme dan pemodelan) terhadap hasil belajar menulis puisi. Pengaruh interaksi yang dimaksud adalah pengaruh interaksi antara teknik menulis puisi dengan dengan kreativitas terhadap hasil belajar menulis puisi. Adapun hasil perhitungan Anava 2 jalur ini secara ringkas dapat dilihat pada Tabel 5. 
Tabel 5. Rangkuman Hasil Perhitungan Anava 2 × 2

\begin{tabular}{|c|c|c|c|c|c|c|}
\hline \multirow{2}{*}{$\begin{array}{l}\text { Sumber } \\
\text { Variansi }\end{array}$} & \multirow{2}{*}{ JK } & \multirow{2}{*}{ dk } & \multirow{2}{*}{$\mathbf{R k}$} & \multirow{2}{*}{$\mathbf{F}_{\text {hitung }}$} & \multicolumn{2}{|c|}{$\mathbf{F}_{\text {tabel }}$} \\
\hline & & & & & $\alpha_{0.05}$ & $\alpha_{0.01}$ \\
\hline Baris $(\mathrm{B})$ & 31.1136 & 1 & 31.1136 & 4.0599 & 4.08 & 7.31 \\
\hline Kolom(K) & 42.0227 & 1 & 42.0227 & 5.4834 & 4.016 & 7.112 \\
\hline Interaksi (BK) & 794.7500 & 1 & 794.7500 & 103.704 & 4.016 & 7.112 \\
\hline Dalam (d) & 306.5455 & 40 & 7.6636 & \multirow{2}{*}{\multicolumn{3}{|c|}{$\begin{array}{c}\text { Ket. } \mathrm{H}_{\mathrm{o}}: \mathrm{A}, \mathrm{B} \& \mathrm{AB}=\text { diterima; } \mathrm{H}_{1} \text { diterima } \\
\text { pada } \mathrm{F}_{\text {hitung }}>\mathrm{F}_{\text {tabel }} \\
(\alpha=0,05)\end{array}$}} \\
\hline Total (T) & 1174.4318 & 43 & 875.5500 & & & \\
\hline
\end{tabular}

Berdasarkan rangkuman perhitungan Anava 2 jalur di atas, maka dapat dijelaskan sebagai berikut.

a. Hipotesis pertama; pada tabel Anava diperoleh harga $\mathrm{F}_{\text {hitung }}=$ $5.4834>\mathrm{F}_{\text {tabel }}$ pada $\alpha_{0,05}=4.016$ sehingga hipotesis nol $\left(\mathrm{H}_{0}\right)$ ditolak dan menerima hipotesis alternatif yaitu terdapat perbedaan hasil belajar menulis puisi yang menulis melalui teknik konstruktivisme diduga lebih besar daripada hasil belajar menulis puisi yang menulis puisi dengan pemodelan.

b. Hipotesis kedua; $\mathrm{Q}_{\text {hitung }}=12,53$ lebih besar $\mathrm{Q}_{\text {tabel }}=5.25$. Hal ini berarti $\mathrm{H}_{1}$ diterima dan menolak $\mathrm{H}_{0}$. Dengan demikian hipotesis yang menyatakan bahwa hasil belajar menulis puisi bagi siswa yang memiliki kreativitas tinggi yang menulis melalui teknik konstruktivisme diduga lebih besar daripada hasil belajar menulis puisi pada siswa yang menulis melalui pemodelan, diterima secara sangat signifikan pada $\alpha \square=0,01$.

c. Hipotesis ketiga; $Q_{\text {hitung }}=3,93$ lebih besar $Q_{\text {tabel }}=2,95$. Hal ini berarti $\mathrm{H}_{1}$ diterima dan menolak $\mathrm{H}_{0}$. Dengan demikian hipotesis yang menyatakan bahwa hasil belajar menulis puisi bagi siswa yang mempunyai kreativitas rendah yang menulis melalui pemodelan diduga lebih besar daripada hasil belajar menulis puisi pada siswa yang menulis melalui teknik konstruktivisme, diterima secara sangat signifikan pada $\alpha$ $=0,01$.

d. Hipotesis keempat; pada tabel Anava diperoleh harga $\mathrm{F}_{\text {hitung }}=$ $103.704>\mathrm{F}_{\text {tabel }}(\alpha=0,01)=$ 7.112 sehingga hipotesis nol $\left(\mathrm{H}_{0}\right)$ ditolak dan hipotesis kerja $\left(\mathrm{H}_{1}\right)$ diterima. Artinya Terdapat terdapat interaksi antara penerapan menulis puisi dengan teknik konstruktivisme, metode pemodelan dan kreativitas awal terhadap hasil belajar menulis puisi.

Berdasarkan hasil pengujian Anava terhadap adanya interaksi yang sangat signifikan antara interaksi antara penerapan menulis melalui teknik konstruktivisme, metode pemodelan, dan kreativitas terhadap hasil belajar menulis puisi, maka untuk menyatakan adanya perbedaan pengaruh dari interaksi kedua variabel tersebut terhadap hasil belajar menulis puisi dilakukan pengujian lanjutan dengan uji Tuckey.

\section{Pembahasan}

Berdasarkan pengujian hipotesis di atas terlihat bahwa teknik menulis puisi telah memberikan pengaruh terhadap hasil belajar menulis puisi yang memiliki kreativitas yang berbeda. Hal itu ditunjukkan oleh hasil perhitungan secara statistika skor tes akhir. Artinya, secara keseluruhan hasil belajar 
menulis puisi bagi siswa yang menulis dengan teknik konstruktivisme maupun yang menulis dengan motede pemodelan memberikan perbedaan yang signifikan.

Pada dasarnya kegiatan menulis adalah kegiatan untuk menghasilkan karya puisi. Kemampuan dan kreativitas menulis tentu tidak sama oleh setiap siswa, mengingat kemampuan mereka berbeda-beda, terutama kreativitas awal siswa. Aktivitas menulis adalah kegiatan yang paling banyak dilakukan selama menuntut ilmu di sekolah atau perguruan tinggi. Hampir setiap hari keharusan menulis dilakukan. Sebagian besar waktu siswa hanya bergelimang dengan kegiatan belajar.

Teknik konstruktivisme merupakan salah satu teknik yang dapat digunakan dalam pembelajaran menulis puisi. Konstruktivisme adalah proses membangun atau menyusun pengetahuan baru dalam struktur kognitif siswa berdasarkan pengalaman. Penulisan puisi dengan teknik konstruktivisme meliputi tahap prapenulisan, tahap penulisan, dan tahap revisi. Tahap prapenulisan siswa dituntut menulis puisi mulai penentuan judul hingga mengungkapkan ide/gagasan. Lalu tahap penulisan, siswa mengembangkan gagasan berdasarkan judul yang ditentukan sebelumnya sehingga menjadi sebuah puisi. Kemudian, tahap revisi siswa melakukan revisi puisi yang ditulis, baik dari aspek diksi, gagasan, tipografi, dan kedalaman gagasan yang dituangkan.

Setelah dilakukan perhitungan hasil belajar menulis puisi, maka pada hipotesis pertama diterima hipotesis alternatif yaitu terdapat perbedaan hasil belajar menulis puisi antara siswa yang menulis dengan teknik konstruktivisme diduga lebih besar daripada hasil belajar menulis puisi siswa yang menulis dengan metode pemodelan. Hal ini menunjukkan bahwa penerapan teknik konstruktivisme dapat meningkatkan keterampilan siswa menulis puisi, terutama pada siswa yang memiliki kreativitas yang tinggi.

Kemampuan setiap siswa dalam menulis selalu menunjukkan perbedaan. Hal ini tentu saja dipengaruhi oleh perkembangan intelektual siswa. Minat biasanya mempunyai andil yang cukup berarti dalam kegiatan menulis seseorang. Tetapi minat tidak bisa dijadikan sebagai faktor penentu baik atau buruknya kemampuan menulis seseorang dalam belajar.

Siswa yang memiliki kreativitas tinggi, menulis dengan teknik konstruktivisme dapat meningkatkan keterampilan mereka dalam menulis puisi. Hal ini didasarkan pada kenyataan bahwa siswa dituntut untuk menghasilkan puisi berdasarkan dengan pengalaman mereka sebelumnya, lalu dikonstruksi berdasarkan bahasa dan objek yang dipilih siswa. Sebaliknya, menulis dengan metode pemodelan, siswa dituntut untuk mengoptimalkan sejumlah kemampuannya, baik kemampuan internal maupun kemampuan eksternal dalam menulis puisi.

Hasil belajar menulis puisi bagi siswa yang memiliki kreativitas rendah, dalam penelitian ini menunjukkan bahwa lebih cocok melalui penerapan metode pemodelan. Hal ini tentu sesuai dengan konsep metode pemodelan. Melalui pemodelan atau pemberian contoh puisi yang ada, lalu siswa menulis puisi. Setelah dilakukan perhitungan data hasil belajar, diperoleh data bahwa metode pemodelan cocok diterapkan kepada siswa yang memiliki kreativitas rendah.

Berdasarkan data perhitungan statistik diperoleh gambaran bahwa terdapat interaksi antara penerapan teknik konstruktivisme, kreativitas, dan hasil belajar menulis puisi. Hal ini tentu tidak dapat diabaikan bahwa dengan melihat pengaruh teknik konstruktivisme, metode pemodelan, dan kreativitas terhadap hasil belajar akan memberikan gambaran yang saling interaktif. Adanya interaksi menunjukkan bahwa antara teknik konstruktivisme dan kreativitas mempengaruhi hasil belajar yang diperoleh oleh siswa dalam menulis puisi. Dengan demikian, hipotesis tentang interaksi teknik konstruktivisme dan kreativitas terhadap hasil belajar diterima.

Berdasarkan hasil pengujian hipotesis penelitian ini, dapat disimpulkan bahwa hasil belajar menulis puisi yang dicapai oleh 
kelompok eksperimen dan kelompok pembanding bukanlah suatu kebetulan, tetapi adalah akibat perlakuan penelitian. Meskipun demikian tidak berarti penelitian ini tidak mempunyai keterbatasan. Berbagai upaya telah dilakukan untuk menjaga kemurnian hasil penelitian ini. Namun, dalam menafsirkan hasil yang diperoleh perlu diperhatikan dan dipertimbangkan beberapa hal yang merupakan keterbatasan penelitian. Keterbatasan yang dapat dipertimbangkan adalah keterbatasan sampel yang terlalu kecil. Ini terjadi karena tidak ada pilihan lain untuk mengoptimalkan jumlah sampel. Keterbatasan lain yang tak kalah pentingnya adalah pengontrolan yang dilakukan terhadap karakteristik siswa hanya meliputi variabel kreativitas saja, tanpa pengontrolan terhadap variabel lain yang dapat mempengaruhi kemampuan siswa dalam menulis puisi. Dengan demikian tidak tertutup kemungkinan masuknya variabel lain yang tidak dikontrol.

\section{Simpulan}

Pertama, secara keseluruhan hasil belajar menulis puisi bagi siswa yang belajar dengan teknik konstruktivisme maupun yang belajar dengan metode pemodelan memberikan perbedaan yang signifikan. Ini berati bahwa teknik konstruktivisme memberikan pengaruh yang lebih besar terhadap hasil belajar menulis puisi jika dibandingkan dengan metode pemodelan.

Kedua, bagi siswa yang mempunyai kreativitas tinggi, teknik konstruktivisme memberikan hasil belajar menulis puisi yang lebih besar jika dibandingkan dengan hasil belajar menulis puisi melalui metode pemodelan.

Ketiga, bagi siswa yang mempunyai kreativitas rendah, teknik konstruktivisme memberikan hasil belajar menulis puisi yang lebih kecil jika dibandingkan dengan hasil belajar menulis puisi melalui metode pemodelan.

Keempat, terdapat interaksi antara teknik menulis dan kreativitas terhadap hasil belajar menulis puisi. Ini berarti bahwa teknik konstruktivisme lebih unggul daripada metode pemodelan bagi siswa yang mempunyai kreativitas tinggi, sedangkan bagi siswa yang mempunyai kreativitas rendah lebih cocok dengan metode pemodelan.

\section{Saran}

1. Kualitas pembelajaran mata pelajaran bahasa Indonesia pada umumnya dan menulis puisi khususnya akan lebih baik jika diterapkan model pembelajaran yang dapat mengaktifkan suasana belajar mahasiswa. Untuk itu, disarankan agar guru memilih dan menggunakan teknik menulis dengan mempertimbangkan faktor-faktor teknis dan non teknis. Artinya, teknik pembelajaran menulis yang digunakan hendaknya dipilih dengan cermat agar sesuai dengan karakteristik siswa.

2. Hasil penelitian tentu belum mempresentasikan hasil yang lebih baik sebagaimana harapan para pembaca. Untuk itu, diharapkan kepada para peneliti selanjutnya kiranya dapat mengembangkan penelitian yang berhubungan dengan penerapan teknik menulis puisi.

3. Karena penelitian ini hanya melibatkan sampel yang terbatas, maka untuk penelitian selanjutnya disarankan agar dapat melibatkan sampel yang lebih besar serta objek garapannya lebih luas, sehingga dapat diperoleh suatu kesimpulan yang representatif.

\section{Referensi}

Agni, Birany. 2009. Sastra Indonesia Lengkap. Jakarta Timur: PT Buku Kita.

Atmazaki. 1993. Analisis Sajak: Teori, Metodologi, dan Aplikasi. Bandung: Angkasa.

Departemen Pendidikan Nasional. 2005. Materi Pelatihan Terintegrasi Bahasa dan Sastra Indonesia. Jakarta: Departemen Pendidikan Nasional Direktorat Jenderal Pendidikan Dasar dan Menengah Direktorat Pendidikan Lanjutan Pertama. 
Emzir. 2009. Metodologi Penelitian Pendidikan; Kualitatif dan Kuantitatif. Jakarta. PT Rajagrafindo Persada

Gagne, Robert M., 1977. The Conditions of Learning. New York: Holf.

Hasanuddin, WS. 2001. Membaca dan Menilai Sajak: Pengantar Pengkajian dan Interpretasi. Bandung: Angkasa.

Jahja, Yudrik. Psikologi Perkembangan. Jakarta: Kencana Prenada Media Group.

Jamaris, Martini. 2013. Orientasi Baru dalam Psikologi Pendidikan. Bogor: Ghaia Indonesia.

Kosasih, E., 2012. Dasar-Dasar Keterampilan Bersastra. Bandung: Yrama Widya.

Michalko,Michel. 2010. Cracking Creativity the Secrets of Creative Genius. Yogyakarta: Andi Yogyakarta.

Sa'ud, Udin Syaefudin. 2009. Inovasi Pendidikan. Bandung: Alfabeta.

Sanjaya, Wina. 2008. Strategi Pembelajaran berorientasi Standar Proses Pendidikan. Jakarta: Kencana Prenada Media Group.

Semiawan, Conny . 1984. Memupuk Bakat dan Kreativitas Sekolah Menengah. Jakarta: Gramedia.

Stones, Edgar. 1979. Psychology of Education A Pedagogical Approach. New York: Methuen. 